\title{
THE PROVISIONING OF EXPEDITIONS IN THE FIELD
}

\author{
Chairman: Sir EDWARD MELLANBY, G.B.E., K.C.B., F.R.S., Nutrition \\ Building, National Institute for Medical Research, Mill Hill, London, N.W.7
}

\section{Emergency Rations}

By G. R. Hervey and R. A. McCance, Medical Research Council Department of Experimental Medicine, University of Cambridge

If a man succeeds in reaching a boat or a raft after his ship has gone down, and if the temperatures of the air and sea are such that he is not likely to die of cold and exposure within the next few hours, he will require rations. He will require rations also if his aeroplane has a forced landing in the sea or desert or if his mechanical transport breaks down there. Given the necessary storage space, the choice of rations would provide few problems, but in any craft equipped to carry survivors the accommodation is necessarily very limited, and the rations must be designed to be as compact and light as possible. In practice this amounts to making decisions which depend upon many more considerations than might at first be supposed. They may be grouped under four headings.

\section{Physiological principles}

At rest in an equable environment, a healthy man without water loses about $900 \mathrm{ml}$. water daily through the lungs and skin, and about $400 \mathrm{ml}$. in the urine. He generates about $200 \mathrm{ml}$. through his own metabolism (Benedict \& Root, I926; Johnston \& Newburgh, 1930; Ladell, I943; McCance \& Young, 1943-4; Marriott, 1947a-c, 1950; Newburgh, 1950; Hervey \& McCance, 1951-2). His requirements from outside sources are therefore just over a litre a day. If he is to remain in metabolic 'balance' he requires also enough food every day to provide him with I 500-2000 Cal. (Lusk, r928). Ideally, emergency rations should be sufficient to prevent physiological deterioration, but in practice it may be impossible to carry enough of them to do this even for a few days, and some deterioration is unavoidable.

There are about 42 l. water in the body of a $70 \mathrm{~kg}$ man (McCance \& Widdowson, I95 I) and a deficit amounting to $5 \%$ of the body's weight causes discomfort and loss of efficiency; a deficit of $10 \%$ is disabling, and one of $20 \%$ may be lethal (Adolph (and associates), 1947). An inadequate water supply, therefore, leads to rapid deterioration, and even with everything else in his favour a man without water would be unlikely to survive for more than 2 weeks and might die much sooner. 
In the absence of food, life is maintained by the energy supplied by the breakdown of body tissue. This involves a loss of body-weight but does not (as does the loss of body water) lead to gross changes in the cellular and extracellular structures of the body, and over a period of 2 weeks the harmful effects are relatively slight (Lusk, 1928). It might be thought, therefore, that if space were very limited there would be no need to provide food at all, except perhaps for the sake of morale, but this is not actually so, for water economy is not independent of diet. The urine formed during dehydration is maximally concentrated, which means that its volume varies with the output of solids (Hervey, McCance \& Tayler, I946; Rapoport, Brodsky, West \& Mackler, I949; Marriott, 1950). The solids are mainly the endproducts of protein metabolism, and salts. It has been known for a long time that the breakdown of body protein in starvation can be reduced by a generous intake of carbohydrate and fat (Lusk, 1928), but it was not appreciated until recently how small an amount of carbohydrate is required to produce the effect. Table I shows the results of an experiment designed to investigate the effects of replacing part of

Table 1. The effect of replacing $100 \mathrm{ml}$. of a $350 \mathrm{ml}$. ration of water by $96.5 \mathrm{~g}$ carbohydrate for six male subjects. Average figures for the 3 rd day on the rations

$\begin{array}{cccc}\begin{array}{c}\text { Amount of water or carbo- } \\ \text { hydrate given }\end{array} & \begin{array}{c}\text { Protein katabolized } \\ (\mathrm{g})\end{array} & \begin{array}{c}\text { Urine vol. } \\ (\mathrm{ml})\end{array} & \begin{array}{c}\text { Water deficit } \\ (\mathrm{ml})\end{array} \\ 350 \mathrm{ml} . & 78 & 680 & 980 \\ 250 \mathrm{ml} .+96.5 \text { g carbohydrate } & 43 & 360 & 750\end{array}$

a small water ration by carbohydrate (Hervey \& McCance, I95 I-2). The volume of urine and the amount of protein broken down in the day were almost halved, and the calculated deficit of water was reduced by over $200 \mathrm{ml}$. Besides sparing protein the carbohydrate prevented starvation ketosis and slightly reduced the metabolic rates, which also may have contributed something to the saving of water. It is clear that the substitution was advantageous. Ingestion of protein, as might be expected, increases the amount katabolized, and is thus to be avoided when water is scarce.

Giving salt to dehydrated men has been shown to increase their urine volume (McCance \& Young, I943-4). Rations, therefore, should contain as little salt as possible. The shipwrecked man is surrounded by sea water, and it has been suggested from time to time that he could benefit by adding small amounts of it to his water rations (Ladell, I943; Gamble, 1944, 1946-7; Whillans \& Smith, 1948). It is difficult to demonstrate directly a deleterious effect of drinking small amounts of sea water, although there is plenty of evidence that large amounts are uniformly fatal (Critchley, 1943). Since, however, the concentration of salt in sea water is well above the highest concentration ever found in human urine, ingestion of any sea water must increase to some extent the concentration of salt in the body fluids (Hervey \& McCance, I $95 \mathrm{I}-2$ ) and, if a man is in danger of dying from dehydration, can only hasten his end (Black, McCance \& Young, 1943-4). 
Practical rations

On tbe basis of these physiological principles three rations may be suggested (Table 2). The first, which may be termed the desirable ration, should prevent deterioration in a healthy man at rest. The second, or compromise, ration should

Table 2. Composition of three levels of emergency rations, expressed per man per day

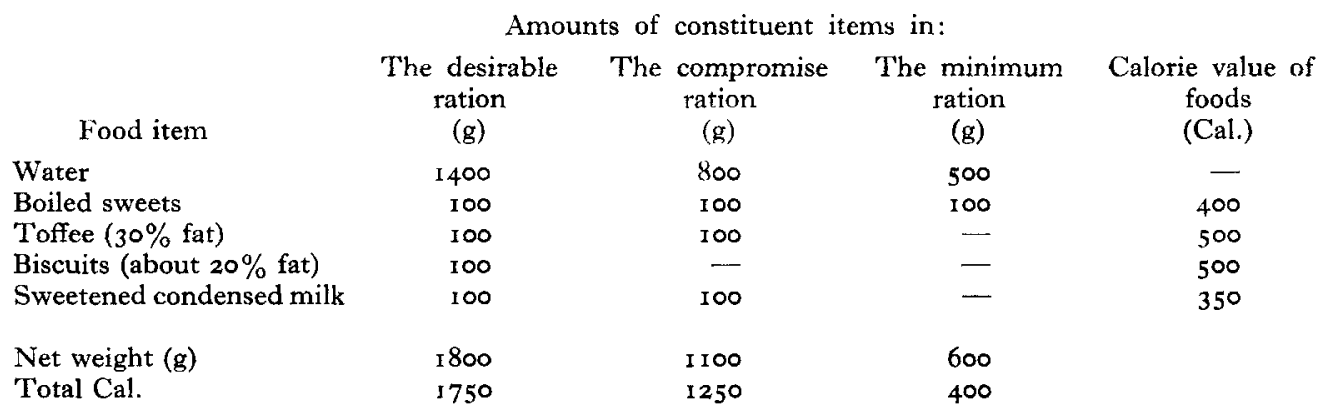

maintain a man in a reasonable state of efficiency for 3 weeks or even longer, and the third is a minimum ration on which a man would lose between I and $2 \%$ of his body-weight a day, but on which he ought to remain fairly well for I week, and survive for 2 or more. Users of the last two rations should probably refrain from taking water on the Ist day and thereafter drink the full ration every day. Nothing is likely to be gained by trying to spin out the water supplies.

There are two striking things about these rations. The first is the weight of the water relative to that of the food, and the second the magnitude of the irreducible weight. It is easy to understand the temptation to reduce weight at the expense of water for, apart from all packing; the desirable rations for 20 men for 5 days would weigh $180 \mathrm{~kg}$. i.e. $396 \mathrm{lb}$. which is over $3 \frac{1}{2} \mathrm{cwt}$.

The individual foodstuffs may no doubt be replaced by better ones but they represent the most calorific, and at the same time the most stable and palatable, products that have so far been devised. The biscuits can be obtained commercially and have been used with success for sledging rations. They might be substituted for the toffee in the 'compromise' ration but many people would find it difficult to eat them if they were short of water (Critchley, 1943). The condensed milk was a practical success during the war. It contains a little protein but can be taken easily by thirsty or injured men. The boiled sweets and the water might be combined as a sweetened, fruit-flavoured drink.

The storage life of these rations is fairly good. The toffee melts at high temperatures but it deteriorates less than chocolate. The condensed milk becomes brown and caramelizes after months at $100^{\circ} \mathrm{F}$. The change makes it less attractive and palatable but probably does not alter its food value. There is scope for some very practical research into storage problems at high temperatures with applications far beyond rations for emergencies. 


\section{The probable time for which rations may be required}

In peacetime ships in distress are usually located before they sink and the survivors are not likely to be adrift for very long; trawlers are perhaps an exception to this generalization. Aircraft, however, travel so rapidly and are forced down at such short notice that a disaster is often followed by a search over a wide area which may go on for some days.

In the last war some men were adrift for 3 weeks or more but the great majority were picked up within a few days of their ship being sunk (Medical Research Council, 1943). This was partly because most merchant ships were travelling in convoy and it is no guide to what may happen in a future war.

Rations, therefore, should be designed on the basis of the probable time for which they may be required, and the calculation may have to be made separately for each ship or aircraft, according to its routing and duties. The storage capacity of the boats or rafts, and the number of men likely to be in them are additional problems that have to be faced before any final decisions can be made.

\section{The environment}

So far the conditions have been assumed to be more or less ideal in calculating physiological requirements and survival times. In practice, the environment may be far from ideal, and whether the same calculations apply depends largely on the equipment.

The motion of small boats, and particularly of rafts, may be very unpleasant, and sea-sickness can greatly increase the loss of water and body fluids, so that hyoscine should be included in the raft equipment and be taken by all. Indeed, hyoscine should if possible be taken before leaving the parent ship (Glaser \& Hervey, 1951, 1952; Anonymous, 1953). Sitting in an open boat in the tropics, exposed to the sun, a man may lose up to $5 \mathrm{l}$. water in $24 \mathrm{~h}$ by sweating (Gamble, 1944). Working would increase the loss, and it may be much higher in a desert (Adolph \& Dill, 1938) (Table 3). Failure to appreciate such heightened loss and to prepare for it has been the cause of much loss of life, but it is rarely practicable

Table 3. Influence of environment and activity on the amount of water lost through evaporation by human subjects

Factors affecting amount of water lost

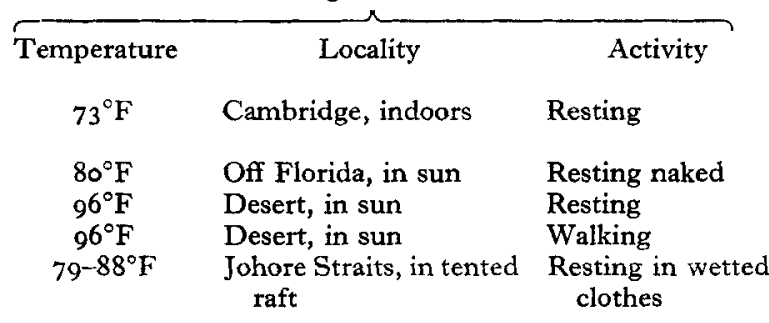

\begin{tabular}{|c|c|}
\hline $\begin{array}{c}\text { Amount of water } \\
\text { lost } \\
(1 / h)\end{array}$ & Reference \\
\hline 0.035 & $\begin{array}{l}\text { Hervey \& McCance } \\
\text { (I95I-2) }\end{array}$ \\
\hline 0.41 & Gamble (I944) \\
\hline 0.68 & Adolph \& Dill (1938) \\
\hline$I \cdot 12$ & Adolph \& Dill (1938) \\
\hline 0.035 & $\begin{array}{l}\text { Glaser \& Hervey } \\
\quad\left(195^{\circ}\right)\end{array}$ \\
\hline
\end{tabular}


to provide water on the necessary scale in emergency rations. Its loss can, however, be reduced by the provision of shade and by avoiding any exertion, and the new inflatable rubber raft with a tent covering has revolutionized the outlook for survivors. In hot climates it provides shade, and if men lie quietly and keep their clothing wet with sea water during the day their water requirements should not exceed the physiological minimum. In cold climates such rafts provide shelter, and in them the occupants generate enough heat to keep themselves warm, and therefore alive.

\section{REFERENCES}

Adolph, E. F. (and associates) (1947). Physiology of Man in the Desert. Chapters 14 and 17 . New York: Interscience Publishers, Inc.

Adolph, E. F. \& Dill, D. B. (1938). Amer. F. Physiol. 123, 369.

Anonymous (1953). Lancet, 265, 437.

Benedict, F. G. \& Root, H. F. (1926). Arch. intern. Med. 38, 1.

Black, D. A. K., McCance, R. A. \& Young, W. F. (1943-4). F. Physiol. 102, 406.

Critchley, M. (I943). Shipwreck-survivors. A Medical Study. London: J, \& A. Churchill.

Gamble, J. L. (1944). Proc. Amer. phil. Soc. 88, I5 I.

Gamble, J. L. (1946-7). Harvey Lect. 42, 247.

Glaser, E. M. \& Hervey, G. R. (1950). Royal Naval Personnel Research Committee Report no. R.N.P. 50/63 I S.S. 36.

Glaser, E. M. \& Hervey, G. R. (1951). Lancet, 26x, 749.

Glaser, E. M. \& Hervey, G. R. (1952). Lancet, 262, 490.

Hervey, G. R. \& McCance, R. A. (1951-2). Proc. roy. Soc. B, 139, 527.

Hervey, G. R., McCance, R. A. \& Tayler, R. G. O. (1946). Nature, Lond, $157,338$.

Johnston, M. W. \& Newburgh, L. H. (1930). Y. clin. Invest. 8, 147.

Ladell, W. S. S. (1943). Lancet, $245,44 \mathrm{I}$.

Lusk, G. (1928). The Elements of the Science of Nutrition, 4th ed. Chapter 4. Philadelphia: W. B. Saunders Co.

McCance, R. A. \& Widdowson, E. M. (195I). Proc. roy. Soc. B, 138, I15.

McCance, R. A. \& Young, W. F. (1943-4). F. Physiol. 102, 4I 5.

Marriott, H. L. (1947a). Brit. med. F. i, 245.

Marriatt, H. L. (1947b). Brit. med. F. i, 285.

Marriott, H. L. (1947c). Brit. med. F. i, 328.

Marriott, H. L. (1950). Water and Salt Depletion. Chapter 4. Springfield, Ill: Charles C. Thomas.

Medical Research Council (1943). M.R.C. (War) Memor. no. 8.

Newburgh, L. H. (1950). Significance of the Body Fluids in Clinical Medicine, p. 55. Springfield, III: Charles C. Thomas.

Rapoport, S., Brodsky, W. A., West, C. D. \& Mackler, B. (1949). Amer. F. Physiol. 156, 433.

Whillans, M. G. \& Smith, G. F. M. (1948). Canad. F. Res. 26, sect. E, p. 250.

\section{Army Operational Rations}

\section{By H. G. Sмıтн, CPO(FS), War Office, Kingston Barracks, Surrey}

Under normal conditions the soldier is fed according to a standard ration scale based on normal civilian feeding habits. Items of fresh food, such as bread, frozen meat, vegetables and fruit, are provided, and all the necessary cooking equipment is available for preparing the meals. When, however, supply conditions become difficult, as during wartime when troops are situated far from their home bases, tinned equivalents of the fresh items are brought into issue. Such substitution 